\title{
Exclusionary Rules-Is It Time for Change?
}

\author{
Sabine Gless and Laura Macula
}

\begin{abstract}
This chapter explores whether exclusionary rules serve as efficient tools to streamline criminal procedure in a way that safeguards the rights of an accused or whether they exist merely as law on the books with limited actual utility. Relevant benchmarks for the evaluation of exclusionary rules are discussed, in addition to their structure. The question of which characteristics of exclusionary rules optimize the protection of procedural rights is analyzed along with other options to prevent violations. Possible alternatives to exclusionary rules are suggested to help answer the question: Is it time for a change?
\end{abstract}

\section{Exclusionary Rules-Efficient Tools or Illusory Giants (紙老虎)?}

Exclusionary rules have long been a topic of interest for legal scholars and the subject of comprehensive study in law journals and textbooks. ${ }^{1}$ The concept originated in common law and was later adopted by civil law and so-called mixed systems and, most recently, in China. ${ }^{2}$ In the Western world, exclusionary rules are featured in flashy criminal cases, detective novels, and movies. However, in ordinary legal practice, in most countries, the exclusion of evidence by courts appears to

\footnotetext{
${ }^{1}$ Wohlers, 2016 at 427.

${ }^{2}$ For an overview Ho, 2019a passim; Macula, 2019 passim; Jiang, 2019 passim; Turner, 2019 passim; Lin et al., 2019 passim, Weigend, 2019 passim.

\author{
S. Gless $(\bowtie)$ \\ Basel, Switzerland \\ e-mail: Sabine.Gless@unibas.ch \\ L. Macula \\ Faculty of Law, University of Basel, Basel, Switzerland \\ e-mail: Laura.Macula@unibas.ch \\ (C) The Author(s) 2019 \\ S. Gless and T. Richter (eds.), Do Exclusionary Rules Ensure a Fair Trial? \\ Ius Gentium: Comparative Perspectives on Law and Justice 74, \\ https://doi.org/10.1007/978-3-030-12520-2_12
}

Chair for Criminal Law and Criminal Procedure at the Faculty of Law, University of Basel,
} 
be the exception rather than the rule. ${ }^{3}$ Anecdotal evidence depicts evidentiary rules as toothless tigers or illusory giants (紙老虎), and likens them to empty threats made by fictional characters in children's books. Mr Tur Tur appears as a giant when seen from afar, but shrinks to normal size as soon as one approaches him. ${ }^{4} \mathrm{~A}$ closer look at exclusionary rules reveals that while they are lauded as indispensable in legal literature, their practical impact is more akin to the fictional characters described above, which raises doubts about their raison d'être, or reason for existence.

This chapter explores whether exclusionary rules serve as efficient tools to streamline criminal procedure in a way that safeguards the rights of an accused ${ }^{5}$ or whether they exist merely as law on the books with little utility in practice. ${ }^{6}$ For this purpose, standards for the evaluation of exclusionary rules are discussed, as is the structure of exclusionary rules with particular detail paid to the question of what characteristics appear to optimize the protection of procedural rights. Thereafter, existing alternatives to prevent violations of procedural rights are examined alongside alternatives to exclusionary rules. Finally, the question is posed, is it time for a change? ${ }^{7}$

\subsection{Standards for the Evaluation of Exclusionary Rules}

The first question in the assessment of the impact of exclusionary rules is, what are the expectations of such rules and what goals they are intended to achieve? This question is difficult to answer as it varies throughout different criminal justice systems. As pointed out by Jenia Turner, Thomas Weigend and Ho Hock Lai, exclusionary rules can serve a multitude of purposes, including safeguarding individual rights, protecting the integrity of procedures, achieving reliable fact-finding, and deterring police misconduct. ${ }^{8}$

\footnotetext{
${ }^{3}$ Calabresi, 2003 at 112 et seq.; Caldwell/Chase, 1994 at 65; Geller, 1975 at 671; Ho, 2019a at 4 et seq. and 10; Macula, 2019 at 3.1.3, 3.2.4.2, 3.2.5.2 and 4; Jiang, 2019 at 3.2.3.2, 3.2.5.2, 3.3.2.2, 3.3.4.2 and 4; Slobogin, 2013 at 341 et seq.; Starr, 2009 at 1514 et seq.; Turner, 2019 at 4 and 5; Lin et al., 2019 at 4, Weigend, 2019 at 3.1.1.1 et seq., 3.2.6, 3.3.2 and 5; Wohlers/Bläsi, 2015 at 167 et seq., all with further references.

${ }^{4}$ See Michael Ende, Jim Knopf und Lukas der Lokomotivführer, 1960.

${ }^{5}$ Giannoulopoulos, 2007 at 181; Ormerod/Birch, 2004 at 141; Pakter, 1985 at 56; Pattenden, 2006 at 13; Roberts/Hunter, 2013 at 176 et seq.; see also arguments provided by the Association for the Prevention of Torture <http://www.apt.ch/en/evidence-obtained-through-torture> accessed 21 November 2018.

${ }^{6}$ Gless, 2018 at 159 et seq.

${ }^{7}$ See for that discussion e.g. US Supreme Courts in Hudson v. Michigan, 547 US 586, 591, 599 (2006); Greco, 2018, 485, 512.

${ }^{8}$ Turner/Weigend, 2019 at 2. Regarding the fair trial rationale, see Ho, 2019b, at 1 et seq.; regarding the judicial integrity rationale, see Ho, 2014 at 112; Taslitz, 2013 at 419 et seq.
} 
Legal goals vary from jurisdiction to jurisdiction, and most systems have several rationales behind the creation of a law. What follows are vast differences in the degree of protection of individual rights and the exclusionary rules themselves. ${ }^{9}$ Often, exclusionary rules serve different purposes in different situations. ${ }^{10}$ Excluding evidence may potentially hinder the pursuit of truth (e.g., excluding illegally taped communications) or promote valid fact-finding (e.g., excluding confessions elicited through torture).

It is often assumed that authorities will refrain from violating individual rights during criminal investigations if the consequence is the exclusion of the evidence obtained. ${ }^{11}$ Naturally, the effectiveness of exclusionary rules in deterring misconduct will depend on a variety of factors that differ across jurisdictions, but important aspects are (1) the likelihood that tainted evidence is identified and exclusionary rules are applied in a timely manner, and (2) whether or not the costs of implementing such a procedure are unduly burdensome on law enforcement and prosecutors. Additionally, if the goal of developing exclusionary rules is to deter misconduct during investigations, such rules must be designed in a way that prohibits any gain from illegally obtained evidence. Or phrased differently, exclusionary rules must be created in a way that the risks of engaging in misconduct outweigh the potential benefits. ${ }^{12}$ This notion is the rationale behind the common law fruit of the poisonous tree doctrine.

The aforementioned concepts beg the question of whether or not the impact of exclusionary rules as a deterrent could potentially be quantified by counting the number of cases in which tainted evidence has successfully been contested and excluded from trial. ${ }^{13}$ Unfortunately, not only do we lack the necessary empirical data (not to mention it is unlikely it will ever exist in a representative and consolidated form), ${ }^{14}$ but any such pursuit would only tell half the story. It would be impossible to measure the full impact of such a deterrent given the difficulty of identifying cases in which the impending exclusion of evidence might actually have prevented misconduct in the first place. The rare exclusion of evidence in case law,

\footnotetext{
${ }^{9}$ Turner/Weigend, 2019 at 1 et seq.

${ }^{10}$ Starr, 2009 at 1566.

${ }^{11}$ Turner/Weigend, 2019 at 3.2.

${ }^{12}$ In detail Starr, 2009 at 1522 with further references. For a behavioural theory approach to deterrence, see Slobogin, 1999 at 373 et seq.

${ }^{13}$ Shereshevsky, 2015 at 92 et seq.

${ }^{14}$ Caldwell/Chase, 1994 at 50; Ho, 2019a at 10.; Macula, 2019 at 4; Jiang, 2019 at 4; Lin et al., 2019 at 4, Weigend, 2019 at 3.1.1.1 et 4. Some empirical studies have been made, however, for the US Oaks, 1970 at 665 et seq.; Orfield, 1987 at 1016 et seq., for China Zuo/Lan, 2019. Also the evaluation of expert interviews made during this project in Knickmeier, 2019. A further problem is that strongly conflicting conclusions can be drawn based on the few empirical data available, Jacobi, 2011 at 110 et seq., pointing out that empirical data produced conflicting conclusions on exclusionary rules due to the selection bias, for instance. Also Slobogin, 1999 at 368 et seq.
} 
which, at first glance, might be discouraging, likely only represents a fraction of the overall effectiveness of exclusionary rules as a deterrent, not to mention other goals.

Aside from the lack of empirical data, the anecdotal evidence gathered during our project overwhelmingly indicates that courts are quite reluctant to apply exclusionary rules due to a hesitancy to reject otherwise relevant evidence in the pursuit of the truth. ${ }^{15}$ The disparity between the attention paid in the literature to the various theories behind exclusionary rules and the few actual cases of evidentiary exclusion is striking. However, even though one finds little analytical reflection in most textbooks and standard legal publications often just assume exclusionary rules are a critical foundation of legal institutions and ensure fairness in criminal proceedings without delving into the doubts, a closer look at their practical application reveals certain weaknesses of exclusionary rules.

\section{$1.2 \quad$ Structural Inefficiency in Exclusionary Rules}

A cursory glance indicates that exclusionary rules cost substantial time and money in what are generally overburdened criminal justice systems. ${ }^{16}$ These apparent expenses seem justified only if exclusionary rules can in fact safeguard procedural rights.

\subsubsection{Limited Scope: Are Only the Guilty Protected?}

However, several aspects have been pointed out over the years that might raise doubts whether resources allocated to exclusionary rules are a wise investment, among them: Exclusionary rules do not trigger a consequence for violating procedural rules unless potentially excludable evidence is obtained in the first place. If there is no evidence to exclude, perhaps because a suspect does not confess or is eventually exonerated, the investigators violating the law suffer no consequences. ${ }^{17}$ It is for this reason that some scholars argue exclusionary rules only protect the guilty. ${ }^{18}$

A similar argument can be made in the case of the illegal procurement of irrelevant evidence. Such evidence usually is not presented to the court and, therefore, cannot be excluded. ${ }^{19}$ On the other hand, the application of exclusionary rules might even prove disadvantageous for a defendant if the illegally obtained

\footnotetext{
${ }^{15}$ See above at 1 , footnote 2 .

${ }^{16}$ Caldwell/Chase, 1994 at 52; Geller, 1975 at 679 et seq. with further references; Kafka, 2001 at 1926; Starr, 2009 at 1520; Wilkey, 1982 at 532 and 534 et seq. with further objections.

${ }^{17}$ Webster, 1982 at 703 and 713.

${ }^{18}$ Kafka, 2001 at 1922; Wilkey, 1982 at 532.

${ }^{19}$ Geller, 1975 at 669 with further references.
} 
evidence is exonerating. ${ }^{20}$ Nevertheless, none of these issues would impact the deterrent effect of an exclusionary rule because law enforcement personnel are not privy to evidence before it is uncovered. ${ }^{21}$

\subsubsection{Between a Rock and a Hard Place}

If evidence has been obtained illegally, courts are faced with the decision to either exclude relevant evidence or use tainted information. They either allow a potentially guilty defendant walk free or fail to provide a remedy for violations of procedural rules and a defendant's rights. $^{22}$

The possibility of setting a guilty defendant free by excluding relevant and reliable evidence seems to be viewed by courts as particularly undesirable. ${ }^{23}$ It interferes with a deeply-rooted sense of justice and responsibility towards victims and the public. ${ }^{24}$ These notions are also captured in sentencing goals, including retribution, deterrence, incapacitation, rehabilitation, and condemnation of wrongdoing. ${ }^{25}$ In both adversarial and inquisitorial systems the public expects reliable evidence to be used to establish the truth. Accordingly, prosecutors are under considerable pressure and, while the public may support the hypothetical use of exclusionary rules, both parties may feel differently when a court excludes seemingly reliable and crucial evidence. ${ }^{26}$ In systems where judges are elected they may fear making such unpopular decisions could result in their not being re-elected. ${ }^{27}$ However, it should be noted that any of the above concerns do not apply in cases where the violation of procedural rights affected the reliability of the evidence as in the case where torture or coercion are utilized. ${ }^{28}$ Furthermore, this idea that the public may have, that individuals who commit murder are able to walk free as a result of exclusionary rules is hardly conform with reality. ${ }^{29}$ In the US, for example, exclusionary rules are more often applied in cases of minor offenses like drug

\footnotetext{
${ }^{20}$ In detail on this controversy Erb, 2017 at 113 et seq.

${ }^{21}$ Geller, 1975 at 669; Thaman, 2013 at 408.

${ }^{22}$ Geller, 1975 at 675 et seq. with further references; Shereshevsky, 2015 at 85; Starr, 2009 at 1510 et seq. and 1538. Also Wilkey, 1982 at 533 criticizing that the exclusionary rule is not proportional to the crime of the accused and the misconduct of the officer.

${ }^{23}$ Calabresi, 2003 at 111 et seq.; Orfield 1992, at 119; Wilkey 1982 at 532 et seq.

${ }^{24}$ Caldwell/Chase, 1994 at 50 et seq.; Estreicher/Weick, 2010 at 951 and 966; Kafka, 2001 at 1925 et seq.; Wilkey, 1982 at 534.

${ }^{25}$ Starr, 2009 at 1543 and 1547.

${ }^{26}$ Geller, 1975 at 674 et seq. and 678 with further references; Starr, 2009 at 1529; Thommen/ Samadi, 2016 at 84; Vetterli, 2012 at 450.

${ }^{27}$ Geller, 1975 at 676 et seq. with further references; Jacobi, 2011 at 169; Rychlak, 2010 at 241; Starr, 2009 at 1516; Wilkey, 1982 at 534.

${ }^{28}$ Calabresi, 2003 at 111; Shereshevsky, 2015 at 73 and 86.

${ }^{29}$ Taslitz, 2013 at 467 et seq., however, argues that some studies suggest that the informed public supports exclusionary rules because of its importance for judicial integrity.
} 
possession. ${ }^{30}$ Even if this were not the case, as one legal scholar pointed out, "rather than take advantage of public 'lack of understanding,' our courts should fulfil their great educative role by explaining the importance of safeguarding fundamental rights." 31

The conclusion that can be drawn from both practical reports and this project's research is that courts all over the world are reluctant to exclude evidence ${ }^{32}$ : Perhaps this is due to the fact that "when faced with all-or-nothing remedial choices, courts tend to choose nothing,"33 which is particularly the case for serious offenses like murder. ${ }^{34}$ Courts even tend to interpret the underpinning rights restrictively to narrow down the scope of an exclusionary rule and be able to admit evidence. $^{35}$ Naturally, if the exclusion of evidence is rarely granted, it cannot adequately protect the underlying individual rights. ${ }^{36}$ Furthermore, the inconsistent narrowing of the law in order to avoid the exclusion of evidence leads to legal uncertainty, which in turn renders compliance even more difficult. ${ }^{37}$

This concern of letting the guilty walk free is emblematic of the underlying difficulties faced by legal systems seeking to ensure the substantive rights of defendants and is beyond the scope of exclusionary rules. ${ }^{38}$ The question then becomes whether or not law enforcement and the public at large can change their mindset about exclusionary rules. The problems faced in a criminal investigation, the significance of a defendant's rights, and the potential for such rights to be violated must be explained to the broader public. Everyone should understand that if misconduct by law enforcement rises to the level for which the legislature established an exclusionary rule, it must be respected in practice, and doing so is in the public's interest. The segregation of society from an accused impedes the effectiveness of exclusionary rules. ${ }^{39}$ Defendants should be seen for who they are: members of society under suspicion of committing a crime. A defendant's individual rights should not be taken lightly.

\footnotetext{
${ }^{30}$ Regarding some US states Geller, 1975 at 676 et seq. and Kamisar, 2003 at 131 et seq. with explanations and further references; Slobogin, 2013 with further references; regarding the jurisprudence of the ECtHR Oberholzer, 2012 at no. 700 et seq. Dissenting Jacobi, 2011 at 170; Kafka, 2001 at 1927; Orfield, 1992 at 117 et seq.; Wilkey, 1982 at 536 et seq. with further references states that "the multitude of criminals who go free because of the exclusionary rule are those who have committed such hateful crimes as murder, rape, and drug trafficking."

${ }^{31}$ Geller, 1975 at 678.

${ }^{32}$ See above at 1 , footnote 2 .

${ }^{33}$ Starr, 2009 at 1517.

${ }^{34}$ Kamisar, 2003at 132 with further references; Oberholzer, 2012 at no. 700 et seq.

${ }^{35}$ Calabresi, 2003 at 112 et seq.; Caldwell/Chase, 1994 at 53 et seq.; Estreicher/Weick, 2010 at 951 with further references; Geller, 1975 at 682 et seq. with further references; Jacobi, 2011 at 168 et seq.; Starr, 2009 at 1515, 1518 and 1563.

${ }^{36}$ Starr 2009 at 1511, 1532, 1537 et seq. and 1565.

${ }^{37}$ Jacobi, 2011 at 171.

${ }^{38}$ Kamisar, 2003 at 134 with further references.

${ }^{39}$ Geller, 1975 at 681 with further references.
} 


\subsubsection{Empty Threats? Exclusionary Rules as Deterrents}

The efficacy of exclusionary rules as deterrents is questionable on a practical level, ${ }^{40}$ particularly in cases where the police do not expect a prosecution ${ }^{41}$ and are not anticipating going in front of a judge and explaining the techniques by which they obtained evidence. It is very difficult to assess how law enforcement officials respond to exclusionary rules ${ }^{42}$ and past studies have asserted that empirical data has been unable to substantiate or refute a deterrent effect. ${ }^{43}$ Nevertheless, some presumptions can be made. First, scholars point out that, with the exception of a potential blow to the ego, the exclusion of evidence imposes no personal cost on police officers engaging in misconduct. ${ }^{44}$ Second, if police officers are more concerned with arrests rather than convictions, they are not likely to be deterred in the heat of the moment with the threat of an exclusionary rule that may or may not be used in the distant future. ${ }^{45}$ In situations ripe for abuse obtaining admissible evidence may not even be the primary objective. ${ }^{46}$ In cases where the authorities need informants rather than information ${ }^{47}$ or are looking to scare potential suspects, ${ }^{48}$ exclusionary rules may not prevent the use of illegal force. In other situations, police may be prone to taking liberty with individual rights to show they are tough on crime ${ }^{49}$ In many criminal justice systems, officials who violate an exclusionary rule never learn whether or not the evidence they obtained is excluded. ${ }^{50}$ Some scholars have gone one step further and claim that the exclusionary rule incentivizes the police to perjure themselves in denying misconduct rather than deterring the misconduct itself. ${ }^{51}$

\footnotetext{
${ }^{40}$ See, for instance, Slobogin, 1999 at 368 et seq. For an attempt to empirically evaluate the deterrent effect of the exclusionary rule, see Oaks, 1970 at 672 et seq.

${ }^{41}$ Sklansky, 2008 at 581 et seq. with further references.

${ }^{42}$ Wilkey, 1982 at 533; see above at 1.1 .

${ }^{43}$ Geller, 1975 at 651 et seq. with further references. These studies, however, were later interpreted to disprove the deterrent effect of the rule, see Geller, 1975 at 662 et seq. with further references.

${ }^{44}$ Caldwell/Chase, 1994 at 56; Geller, 1975 at 665 et seq. with further references; Jacobi, 2011 at 114 et seq.; Slobogin, 1999 at 372.

${ }^{45}$ Jacobi, 2011 at 119; Kafka, 2001 at 1923 et seq. with further references.

${ }^{46}$ Caldwell/Chase, 1994 at 55 et seq. with further references.

${ }^{47}$ In detail Geller, 1975 at 667 et seq. with further references.

${ }^{48}$ Jacobi, 2011 at 119 et seq.

${ }^{49}$ Calabresi, 2003 at 117; Kafka, 2001 at 1922 et seq. with further references.

${ }^{50} \mathrm{Caldwell} / \mathrm{Chase}, 1994$ at 53 with further references.

${ }^{51}$ Jacobi, 2011 at 121 et seq. and 170 with further references.
} 


\subsection{To Replace or Enhance Exclusionary Rules?}

In response to the above critiques of exclusionary rules, one could ask if they should be modified or replaced altogether. These positions are intertwined and trigger additional questions: What types of legal frameworks can actually safeguard individual rights at risk during criminal fact-finding? How must exclusionary rules be written to enhance respect for the rights of defendants and witnesses? These positions are not mutually exclusive and existing criminal justice systems illustrate that a combination of enhancement and alternatives may be the best option.

\section{Are Exclusionary Rules Inherently Disadvantaged?}

Based upon the hypothesis that exclusionary rules are essentially a means to safeguard individual rights in criminal proceedings but with little practical impact, the question arises: What kind of institutional, procedural, and factual conditions are required to optimize the effectiveness of exclusionary rules?

\subsection{Institutional Framework}

A certain degree of institutional structure is necessary to successfully enforce procedural rules, the first and foremost of which is respect for the rule of law. Only where all people and institutions are subject to the law and held accountable can the threat of an exclusionary evidentiary rule have an impact. ${ }^{52}$ Furthermore, a general commitment to human rights, ${ }^{53}$ including those of the accused standing trial, is a necessary prerequisite for the acceptance of exclusionary rules. ${ }^{54}$

In addition to the statutory structure, the organizational structure of a criminal justice system is crucial to the effectiveness of exclusionary rules. The division of power and finances both play a role, as does the education of law enforcement personnel $^{55}$ and the salaries of police officers, prosecutors, and judges. ${ }^{56}$ Most criminal justice systems have developed specific frameworks in which checks and balances are created in an effort to prevent abuse. Clear administrative hierarchies

\footnotetext{
${ }^{52}$ Exclusionary rules and the acceptance of the rule of law seem closely connected in various criminal justice systems, for Germany see: Gless in Löwe/Rosenberg, 2007 at $§ 136$ a note 1; for China see Jiang, 2019 at 1 and 3.2.2 with further references.; for the US see Turner, 2014 at 101 et seq.

${ }^{53}$ Regarding the connection of human rights and exclusionary rules, see Gless, 2018 at 163 et seq.

${ }^{54}$ Summers/Jackson, 2012 at 77 et seq., 151 et seq.

${ }^{55} \mathrm{See}$ below at 3.2.1 et seq.

${ }^{56}$ For example, Solomon, 2010 at 357; Thelle, 2006 at 272.
} 
can foster a culture that does not tolerate abuse, especially where police and prosecutors are integrated into a common chain of command and the requirements of evidence gathering can be supervised throughout the various phases of a criminal investigation. 57

Beyond statutory law, the ethical attitudes of authorities directly involved in evidence gathering are of great importance. The culture of the workplace and the example set by superiors is more likely to shape the behavior of investigators than the rare condemnation by a judge. An exclusionary rule will be of little value as a deterrent if the (unspoken) departmental policy condones illegal methods of obtaining evidence, due, for example, to the enormous public pressure to prosecute. $^{58}$

\subsection{Pitfalls Across Legal Systems}

\subsubsection{In Pursuit of the Truth}

The inquisitorial and adversarial models of criminal justice are often distinguished with regard to their commitments to finding the truth. A firm commitment to discerning the truth is said to be paramount to inquisitorial systems, whereas in adversarial models it might be superseded. ${ }^{59}$ This position dates back to the traditions of the respective jurisdictions. German and Swiss textbooks, for instance, still emphasize determination of the "substantive truth" as the basis for a just and fair outcome in any criminal case. ${ }^{60}$ However, in the everyday of today's inquisitorial systems, legal practice has shifted to use of various plea-bargaining techniques with an emphasis on confessions, thereby prioritizing the closing of cases over finding the truth. In 2009, a variation of plea-bargaining was introduced into the German Code of Criminal Procedure ( $\$ 257 \mathrm{c}$ German CCP). ${ }^{61}$ Meanwhile, in Switzerland today more than $95 \%$ of criminal cases end with a "Strafbefehl," or summary penalty order, rather than prosecution. ${ }^{62}$

Ultimately, in all criminal justice systems there is a gap between theory and practice when it comes to evidentiary exclusion rules. In all jurisdictions there is a strong interest in determining the truth because that is the foundation upon which

\footnotetext{
${ }^{57}$ Geller, 1975 at 721 et seq.; Thaman, 2013 at 408.

${ }^{58}$ Geller, 1975 at 669 et seq. with further references.

${ }^{59}$ Eser, 2014 at 22 et seq.

${ }^{60}$ See for Germany: Kühne, 2015 at 206 et seq.; Roxin/Schünemann, 2017 at 87 et seq.; for Switzerland: Macula, 2019 at 2.1.1.1.

${ }^{61}$ According to that practice, the trial judges and the defense can negotiate a lenient sentence in exchange for the defendant making a confession, in open court, to the crime charged. For further information, see German Country report; regarding similar procedures in Switzerland see Macula, 2019 at 2.1.1.3 with further references.

${ }^{62}$ Macula, 2019 at 2.1.1.3 with further references.
} 
judgments of guilt or innocence ought to be made. To that end, authorities strive for comprehensive fact-finding and exclusionary rules are perceived as undesirable hurdles. ${ }^{63}$ Additionally, courts rarely address the beneficial effects of exclusionary rules in their opinions. ${ }^{64}$ Further, at least in the US, the argument has been made that exclusionary rules can fuel police and prosecutorial misconduct due to a win-at-all-costs mentality which may simultaneously encourage defense attorneys to challenge even minor missteps by police. ${ }^{65}$

\subsubsection{Record Keeping and the Role of the Prosecution}

For inquisitorial systems, well-kept files are the foundation for valid and transparent fact-finding. Each step taken by the police or prosecution must be recorded, with a document placed in a single case file accessible to the defense. The file is eventually sent to the court for a decision. This form of record keeping is basically different from the adversarial system, which has separate files for the prosecution and defense, and which involves specific disclosure proceedings of prosecution material to the defense. The difference accounts for one of the most important characteristics regarding the success of exclusionary rules: In the adversarial system certain evidence may never even reach a jury due to the fact that any (potentially tainted) evidence must first be ruled admissible by a judge following prosecution and defense submissions. When potentially tainted evidence never even reaches a jury, it is more effectively kept out of trials by exclusionary rules. The inquisitorial system, on the other hand, involves a continual fact-finding process, beginning with the prosecution's collection and evaluation of all evidence - both incriminating and exonerating - and subsequent presentation to the court. Notably, the sequencing of events is based upon the narrative of the case file, one consequence of which is the availability of tainted evidence to the bench prior to its being ruled upon. ${ }^{66}$ It seems obvious that the effectiveness of exclusionary rules is in part due to the withholding of tainted evidence from the adjudicator, as is the case in a jury trial. ${ }^{67}$ Within inquisitorial systems this could be achieved by the removal of tainted evidence from the file as early as practically possible. ${ }^{68}$

\footnotetext{
${ }^{63}$ In detail above at 1.2.2. Although in certain situations, exclusionary rules aim at protecting valid fact-finding like in the case of torture evidence.

${ }^{64}$ For more information on the function of exclusionary rules, see Turner/Weigend, 2019 at 2 et seq.

${ }^{65}$ Slobogin, 2013 at 354 with further references.

${ }^{66}$ In fact, in Germany the court will explain in its verdict why tainted evidence cannot be included for fact-finding, see, for example, BGH, Judgement of 6 October 2016 - 2 StR 46/15; AG Kehl, Decision of 29 April 2016 - 2 Cs 303 Js 19062/15.

${ }^{67}$ In detail Wohlers, 2016 at 430 et seq.; also Wohlers/Bläsi, 2015 at 169 et seq.

${ }^{68}$ Wohlers, 2016 at 433 et seq., describing, however, also the practical problems that may arise due to such removal.
} 


\subsubsection{Checks and Balances: Supervision of Evidence Gathering}

Another procedural aspect important for the functioning of exclusionary rules is a system of checks and balances that triggers exclusionary rules during the criminal investigation, not just at trial. Such a system of control and accountability could be shaped in a number of ways. One option could be to involve an outsider, such as a defense representative or an NGO, who could supervise and monitor the evidence gathering process in real time. Evidence obtained without the supervision of this external party would then be excluded and prosecutors and defense attorneys would also be obliged to report police misconduct. ${ }^{69}$ A monitoring regime could also be set-up with technical devices, such as videotapes ${ }^{70}$ or bodycams. This type of a system could have a preventative effect and, in the case of misconduct, help a defendant assert his or her rights under the exclusionary rule while also providing reliable evidence. ${ }^{71}$

\subsubsection{Procedural Protections for Defendants}

The effectiveness of exclusionary rules is also predicated upon certain rights granted to a defendant, namely, access to publicly funded and adequately trained defense counsel. The need for effective assistance of counsel is central to the adversarial criminal justice system and this belief is also shared by most European countries. $^{72}$ In Germany, for instance, the right to consult with a lawyer before being questioned by the police or other law enforcement personnel is an important procedural right that safeguards against potential abuses of power and is the foundation of the right to remain silent. ${ }^{73}$ Similarly, in Switzerland, the right to have a defense lawyer present at the time of the first interview by police personnel is defined in Art. 159 of the Swiss Criminal Procedure Code, which was adopted following several European Court of Human Rights (ECHR) decisions.

\footnotetext{
${ }^{69}$ Hilton, 2008 at 80 et seq.

${ }^{70}$ For Taiwan: Lin et al., 2019 at 2.1.1.2. et seq. and 3.2.4; for Singapore: Ho, 2019a at 6; for the US: Turner, 2019 at 3.4.2; Kamisar, 2003 at 127, with further references; for Germany: the new $\S$ 136 (4) of the German Code of Criminal Procedure explicitly regulating the optional videotaping of the interrogation of the accused. In Switzerland, recent reform efforts plan to amend the CPC by adding a new art. 78a CPC on the recording of interviews with technical devices; see art. 78a of the preliminary draft regarding a reform of the CPC submitted by the Swiss Federal Council in December 2017, available online at <https://www.bj.admin.ch/dam/data/bj/sicherheit/gesetzgebung/ aenderungstpo/vorentw-d.pdf>, accessed 22 November 2018.

${ }^{71}$ Summers/Studer, 2016 at 63.

${ }^{72}$ Art. 6 (3) c) ECtHR; Summers/Jackson, 2012 at 80 et seq. It is likely that this rule will change in light of the case law of the ECtHR since Salduz v. Turkey, case no. 36391/02, Judgment of 27 November 2008.

${ }^{73}$ BGH, Judgement of 22 November 2001 - 1 StR 220/01 (=BGHSt 47, 172).
} 


\subsubsection{Effective Remedies}

Clearly, an efficient remedy is crucial for the functioning of exclusionary rules, i.e. that information obtained through a violation of individual rights can actually be blocked from fact-finding. Without adequate remedies those whose rights have been infringed upon cannot benefit from the procedural protections granted by the law and officials who are inclined to violate procedural rules are not deterred.

Remedies for violations of procedural rules designed to guarantee a fair trial should actually benefit the defendant, otherwise, as a Swiss trial observation study found, ${ }^{74}$ they will not be invoked. Ideally, effective use of exclusionary rules becomes integrated within general practice so that the role of procedural rights does not deteriorate into a theoretical remedy, potentially available by law, but not used due to a restrictive "customary procedure." 75 To this point, the exclusion of evidence is not an effective remedy if it is circumvented by plea-bargaining or if procedural requirements, such as time limitations and prerequisites for standing, are too onerous. Additionally, a defendant should be able to make a motion to exclude evidence for the entirety of the criminal trial. ${ }^{76} \mathrm{He}$ or she should also be granted the opportunity to prohibit tainted evidence from entering the fact-finding process very early in the proceeding. Where, as is often the case in Germany and Switzerland, the admissibility of evidence cannot be challenged separately, but only on appeal following a final judgement, the appellate authority who decides whether or not the evidence should have been admissible also adjudicates guilt or innocence. ${ }^{77}$ In these cases, exclusionary rules run a risk to prove futile.

\subsection{Legislative Techniques to Promote Efficient Exclusionary Rules}

\subsubsection{Improving Statutory Structure}

The design and content of exclusionary rules vary widely across jurisdictions, particularly with regard to their clarity and comprehensiveness. It is also the case that certain statutory schemes are more effective than others. An important aspect to start with, is a clear statutory regime featuring a systematic set of exclusionary rules that is well-integrated into the corresponding procedural code. ${ }^{78}$ Instead, in most jurisdictions, exclusionary rules are shaped by case law in a certain number of cases

\footnotetext{
${ }^{74}$ Summers/Studer, 2016 at 63.

${ }^{75}$ Summers/Studer, 2016 at 64.

${ }^{76}$ Macula, 2019 at 3.1.4.

${ }^{77}$ For Germany, see Weigend, 2019 at 3.1.1; for Switzerland, see Macula, 2019 at 3.1.4.

${ }^{78}$ Vetterli, 2012 at 458 et seq.
} 
and are difficult to access. ${ }^{79}$ Without a clear statutory basis for excluding evidence, motions to exclude it become difficult to substantiate in practice. It is also true that more flexible legal solutions, like the balancing approach used by some courts, risks paving the way for arbitrary decisions. ${ }^{80} \mathrm{With}$ vague and discretionary exclusionary rules, individual rights may not receive the weight they are due. That said, the mere adoption of a statutory exclusionary provision is not the end-all be-all either. If courts find exclusionary rules too inflexible, they might use their decision-making authority to circumnavigate them, ${ }^{81}$ for instance, by narrowly defining the underlying rights. ${ }^{82}$ On the other hand, vague rules may end up promoting misconduct because of a lack of clear rules for police. ${ }^{83}$ Regardless of the model, there remains the risk that tainted evidence will be admitted without a remedy. It is for this reason that the initial drafting of exclusionary rules is optimized by the creation of a law that strives to prevent unforeseeable results and deters investigative authorities from misconduct. ${ }^{84}$ Severe consequences such as mandatory exclusion of evidence obtained through substantial procedural violations (e.g. torture) are better suited to deter such behavior.

\subsubsection{Exclusion of Fruit of the Poisonous Tree}

Throughout this project it became clear that the exclusion of indirect evidence, or fruit of the poisonous tree, has become a sort of litmus test for the effectiveness of exclusionary rules. The importance of this concept is highlighted in cases where particularly disturbing means, such as torture, were used to obtain evidence. In such cases it is not sufficient to simply exclude evidence that was gleaned through torture of the suspect. Rather, only the exclusion of all evidence gained as a consequence of the physical abuse, including derivative or indirect evidence, is apt to deter torture. For example, if a defendant confesses to a murder while being tortured and reveals the location of a dead body, all indirect evidence, such as DNA on the body, should be excluded along with the confession in order to deter state agents from engaging in such behavior. Therefore, the assessment of any legal framework to exclude illegally obtained evidence must be based not only on its capacity to

\footnotetext{
${ }^{79}$ A commendable exception is Switzerland, see Macula, 2019 at 3.1.2, with its comprehensive provision in Art. $141 \mathrm{CH}-\mathrm{CCP}$, that can nevertheless not avoid surprises completely, see Gless/ Martin, 2015 at 178 et seq. In Singapore, as well as in the US or Germany, exclusionary rules involve considerable legal uncertainty, Ho, 2019a at 4 et seq.; Turner, 2019 at 4; Weigend, 2019 at 3.

${ }^{80}$ Macula, 2019 at 3.1.3 with further references. For a comparative overview on the balancing approach see Thaman, 2003 at 403 et seq.

${ }^{81}$ Gless/Martin, 2015 at 178 et seq. and see above at 1.2.2.

${ }^{82}$ Starr 2009 at 1515, 1518 and 1563; also Gless/Martin, 2015 at 178 et seq.; Macula, 2019 at 3.1.3 and 3.2.5.2.

${ }^{83}$ Kafka, 2001 at 1924 et seq.

${ }^{84}$ Geller, 1975 at 666 et seq. with further references; Jacobi, 2011 at 115 et seq.
} 
prohibit coerced confessions from entering criminal proceedings, but the availability to also exclude fruit of the poisonous tree..$^{85}$

\subsection{Interim Conclusion}

Whether exclusionary rules are deemed illusory giants depends on a number of factors, all of which are contingent upon the interaction of key stakeholders, institutions, and the procedural code of each criminal justice system. Independent of culture-specific characteristics, it appears plausible that where a system of checks and balances is in place and where a defendant has standing to challenge tainted evidence, an exclusionary rule can successfully achieve the goal of protecting individual rights. However, the criminal justice system in which the rule is created must also be committed to protecting these rights even where it may result in a guilty defendant walking free. This requires the commitment of all stakeholders involved in order to be effective and such an investment can be difficult to achieve. As such, the question of potential alternatives to exclusionary rules remains.

\section{Alternatives to Exclusionary Rules}

Aside from ways to enhance exclusionary rules discussed in the previous section, potential alternatives must also be addressed. Where courts are unwilling to exclude any information from the fact-finding process as a deterrent to procedural violations during criminal investigations, lawmakers must search for other ways to achieve the same goal. ${ }^{86}$ They can go about this in vastly different ways, such as decriminalization, which would reduce the risk of governmental transgression via global changes to a jurisdiction's criminal code. Preventative measures against police misconduct, enhancement of remedies where law enforcement authorities are held accountable, or other compensation schemes, including sentence reductions or complete dismissals are also possibilities. In order to be effective, such alternatives must be created to incentivize prosecutors and impose real costs on transgressors. ${ }^{87}$ Furthermore, alternative remedies must be more likely to be granted by courts than exclusionary rules - otherwise they do not amount to a viable alternative. ${ }^{88}$

\footnotetext{
${ }^{85}$ Gless, 2018 at 159 et seq.

${ }^{86}$ Kamisar, 2003 at 126 et seq. with further references.

${ }^{87} \mathrm{See}$ above at 1.1 .

${ }^{88} \mathrm{See}$ above at 1.2.1. et seq.
} 


\subsection{Decriminalization}

Decriminalization as an alternative to exclusionary rules involves a number of considerations. First, decriminalization offers the potential benefits of saving resources and prioritizing quality criminal investigation of the remaining crimes. Decriminalization could also act as a means of preventing infringements on individual rights in minor offenses that maybe more prone to abuse by the authorities. In fact, studies have shown that based on a higher number of motions to exclude evidence in such cases, police are particularly tempted to use illegal techniques when investigating crimes sometimes depicted as "victimless," such as illegal drug use and gambling. ${ }^{89}$ However, these findings can be interpreted in a number of ways. Courts may be more inclined to exclude evidence in "victimless" cases as the prospect of allowing a guilty defendant to walk free is more palatable where there is little impact on a victim's interests. ${ }^{90}$ On the other hand, the rarity of evidence exclusion in cases with larger victim impacts may be the result of more diligent and specialized investigations with fewer mistakes or, more realistically, the immense public pressure on courts to admit evidence in such cases, even where it should be excluded. ${ }^{91}$ Given such difficulties, the decriminalization of certain "victimless" offences might be worth considering ${ }^{92}$ as a legitimate means of decreasing violations of human rights by the police. Additionally, the extent to which the threat of punishment offers any social benefit, particularly with regard to such offences, is unclear. Alternatively, if a jurisdiction sought to handle such cases differently, it could implement mandatory exclusion of illegally obtained evidence without judicial discretion and potentially achieve the same goal.

\subsection{Preventative Measures: Establishing Incentives and Reducing Barriers to Procedural Compliance}

Some scholars argue that jurisdictions should focus on promoting constitutional rights in criminal proceedings by preventative measures rather than deterring abuse. $^{93}$

\footnotetext{
${ }^{89}$ Geller, 1975 at 625 with further references; Kamisar, 2003 at 131 et seq. with further references; Oaks, 1970 at 724 .

${ }^{90}$ Oberholzer, 2012 at no. 700 et seq., pointing out that the ECtHR has been more reluctant to exclude evidence in a murder case than in a victimless drug offence. Oberholzer compared the two cases of ECtHR (GC), Gäfgen v. Germany, case no. 22978/05, Judgment of 1 June 2010 and ECtHR (GC), Jalloh v. Germany, case no. 54810/00, Judgment of 11 July 2006.

${ }^{91}$ Kamisar, 2003 at 132.

${ }^{92}$ Geller, 1975 at 624 et seq.

${ }^{93}$ Estreicher/Weick, 2010 at 960.
} 


\subsubsection{Improved Law Enforcement Training}

One way of shaping police behavior proactively is to improve law enforcement training by focusing on developing an understanding of the value of civil liberties and individual rights. ${ }^{94}$ Police officers should be well-informed about criminal procedure and the consequences of rule violations to realize the personal impact. ${ }^{95}$ The same training should specifically focus on developing an awareness among law enforcement personnel that the rights granted to suspects are not without good reason. ${ }^{96}$ An emphasis on ethics is also important, ${ }^{97}$ as are clear and concise evidence gathering guidelines. ${ }^{98}$ Law enforcement training should also provide officers with problem solving strategies that can easily be applied in real-life situations. ${ }^{99}$ In cases of misconduct, educational measures should be implemented: the offending officer (and perhaps his agency) must be informed of his misconduct and he or she should then be required to attend training (preferably during off hours) to remedy the misconduct and to guide future behavior. ${ }^{100}$ Another important aspect of improved law enforcement training is the diligent selection of instructors. If training personnel display a cynical attitude towards the role of police officers and the rights of accused, this will often be adopted by their students. ${ }^{101}$

Training police officers, by itself, may not be enough to deter misconduct. To optimize results, it should be supplemented with incentives for compliance with the law. ${ }^{102}$

\subsubsection{Stress Management Programs}

Police misconduct does not occur in a vacuum. Thus, a preventative approach should also consider the psyche and wellbeing of law enforcement personnel. Studies in the US classify police officers as part of an occupational group that is particularly likely to experience a high level of stress and are far more likely to commit suicide compared to the general population. Stress at work or home can increase the risk that an officer will engage in misconduct. ${ }^{103}$ Accordingly, law enforcement agencies should provide peer support programs, professional

\footnotetext{
${ }^{94}$ On the inadequacy of present law enforcement training in the US, see Hilton, 2008 at 71 et seq.

${ }^{95}$ Estreicher/Weick, 2010 at 961; Hilton, 2008 at 75; critical Slobogin, 1999 at 393 et seq.

${ }^{96}$ Geller, 1975 at 721; see also Hilton, 2008 at 75.

${ }^{97}$ Hilton, 2008 at 75.

${ }^{98}$ Estreicher/Weick, 2010 at 961.

${ }^{99}$ Hilton, 2008 at 75.

${ }^{100}$ Caldwell/Chase, 1994 at 68 et seq. and 74 et seq.; also Hilton, 2008 at 79.

${ }^{101}$ Hilton, 2008 at 76.

${ }^{102}$ Calabresi, 2003 at 114.

${ }^{103}$ Hilton, 2008 at 74.
} 
counselors, and training that includes practical stress management skills to help address the source of a police misconduct. ${ }^{104}$

\subsubsection{Incentive Systems}

Another promising strategy might be to replace or supplement deterrence-based models with a reward model and reporting system that keeps track of misconduct. For example, police officers could receive nominal monetary compensation each time evidence they collected legally was later used in court. An advantage of this solution is its direct and seemingly positive effect on the officials gathering the evidence (the same people who are at risk of violating the rules in the first place). ${ }^{105}$ This option could be successful, especially in countries where torture and mistreatment by authorities remains a major problem. That said, this type of system would increase the time and monetary demands placed upon the administration and could significantly alter the working environment within police departments. Furthermore, such incentive systems may be susceptible to exploitation as police would be encouraged to prioritize the prosecution of certain arrests. ${ }^{106}$ But, for some criminal justice systems, where these risks could be considered sufficiently marginal, such a structure could achieve higher compliance with procedural rules and thus fairer trials for defendants. As with exclusionary rules, these rules and structural changes would only apply to police conduct related to securing evidence for prosecution. ${ }^{107}$ Unfortunately, it would not have an impact upon other misconduct - that which may have no particular purpose or that is motivated by inherent aggression.

One other idea for an incentive system could be to establish standard promotions of officials after a certain period of lawful work. If an official violates important procedural rules during evidence collection, the promotion would be refused and he or she may even be demoted. Promotions could also depend on satisfactory testing results in training courses. ${ }^{108}$

\subsubsection{Elimination of Quotas}

Quota systems pressuring officials to meet a certain number of arrests and summons are inherently flawed. Instead of increasing efficiency within a police department, experts warn that this may lead to cynicism and disillusionment. Officers often experience such quotas as unfair and arbitrarily enforced; they also tend to feel

\footnotetext{
${ }^{104}$ Hilton, 2008 at 74 et seq.

${ }^{105}$ Geller, 1975 at 720 .

${ }^{106}$ Geller, 1975 at 721 .

${ }^{107}$ Geller, 1975 at 721.

${ }^{108}$ Estreicher/Weick, 2010 at 961.
} 
pressured to falsify evidence in order to meet the requirements. ${ }^{109}$ Consequently, such systems should be abandoned to avoid provoking rather than preventing police misconduct.

\subsubsection{Monitoring Evidence Gathering}

The aforementioned measures to monitor evidence gathering, including defense participation and the use of recording protocols, ${ }^{110}$ could also be viewed as an alternative to exclusionary rules due to the potential deterrent effect on prosecutors. Additionally, in order to achieve transparency, law enforcement agencies could be required to maintain a public and regularly updated registry of certain evidence gathering processes such as searches, property seizure, and arrests, as well as complaints stemming from those actions. ${ }^{111}$ This does not, however, represent a viable surrogate to exclusionary rules because not every evidence gathering action can be monitored, nor does monitoring result in consequences for violations of procedural rules that might still occur.

\subsubsection{Injunctive Relief}

In cases of systematic illegal searches and seizures ${ }^{112}$ an injunction to forbid, and thus prevent, any further illegal searches might be a helpful measure to supplement (but not replace) the exclusion of evidence, although courts might be reluctant to grant such a remedy. ${ }^{113}$

\subsubsection{Interim Conclusion}

All of the preventive measures discussed in this section could potentially enhance compliance with procedural rules but they do not stipulate consequences for procedural violations. Thus, a defendant whose rights have been violated will nevertheless be prosecuted using tainted evidence. Therefore, these measures do not constitute adequate replacements for exclusionary rules but could be promising supplementary means.

\footnotetext{
${ }^{109}$ Hilton, 2008 at 70 et seq. and 76.

${ }^{110}$ See above at 2.2.3. et seq.; for internal monitoring measures see Hilton, 2008 at 68.

${ }^{111}$ Estreicher/Weick, 2010 at 953 and 961.

${ }^{112}$ This requirement might make injunctions ineffective, Jacobi, 2001 at 164 et seq.

${ }^{113}$ Geller, 1975 at 715 et seq. with further references; Hilton, 2008 at 61; Sklansky, 2008 at 574.
} 


\subsection{Other Means of Holding Law Enforcement Accountable}

\subsubsection{Claims Under Tort Law}

It has been argued that a modified remedy under tort law, where monetary compensation and damages were awarded, would be superior to exclusionary rules. ${ }^{114}$ As an alternative, it could also act as a supplementary measure in a comprehensive system. ${ }^{115}$ Such a remedy could include both compensatory and punitive damages. ${ }^{116}$ The advantage to this option is that it does not interfere with the primary sentencing goals of punishing the wrongdoer and providing a remedy to the victim/ claimant. ${ }^{117}$ It also follows the idea that where nonpecuniary damages cannot be undone, monetary compensation comes the closest to compensating the damaged party. ${ }^{118}$ Despite this fact, tort actions would face similar and maybe even more issues around efficiency than exclusionary rules, ${ }^{119}$ for instance because public authorities may often be immune to such actions ${ }^{120}$ and a defendant may not have standing to sue while incarcerated. ${ }^{121}$ Additionally, law enforcement officials are likely to be given more credence than criminal defendants and it may be difficult for defendants to prove police misconduct or actual damages. ${ }^{122}$ The typical defendant would also probably lack the resources, energy, time, and knowledge to raise such claims against the authorities, ${ }^{123}$ although these problems could be mitigated by reducing or eliminating certain rules ${ }^{124}$ such as sovereign immunity in the case of significant violations. ${ }^{125}$

\footnotetext{
${ }^{114}$ Especially regarding search and seizure exclusionary rules, see, for instance, Amar, 1994 at 800 et seq.; Kafka, 2001 at 1934 et seq.; Oaks, 1970 at 756 et seq.; Slobogin, 1999 at 384 et seq.; Wilkey, 1982 at 538. For Germany: Greco, 2018, at 512.

${ }^{115}$ Estreicher/Weick, 2010 at 962 et seq.

${ }^{116}$ Amar, 1994 at 812 et seq.; Kafka, 2001 at 1938.

${ }^{117}$ Shereshevsky, 2015 at 90 et seq.

${ }^{118}$ Shereshevsky, 2015 at 91 et seq.

${ }^{119}$ Sklansky, 2008 at 580 et seq.

${ }^{120}$ Estreicher/Weick, 2010 at 949; Starr, 2009 at 1518.

${ }^{121}$ In detail to the problems and to proposals for modifying the tort action Geller, 1975 at 690 et seq. with further references.

${ }^{122}$ Calabresi, 2003 at 114 et seq.; Estreicher/Weick, 2010 at 949; Geller, 1975 at 671 and 692 et seq. with further references; Kamisar, 2003 at 135.

${ }^{123}$ Geller, 1975 at 655 et seq. with further references.

${ }^{124}$ Kafka, 2001 at 1937 with further references.

${ }^{125}$ Amar, 1994 at 812 et seq.; Estreicher/Weick, 2010 at 963 who suggest a waiver of immunity for jurisdictions that want to replace the exclusionary rule with efficient alternatives.
} 


\subsubsection{Official Apologies}

Social science research has found that just the fear of condemnation and the inherent social disapproval of wrongdoing do have a deterrent effect, but only if certain requirements are met. ${ }^{126}$ The wrongdoer must first possess fear around the risk of being discovered and, if misconduct has been identified, the individual must be informed and (optimally) experience a direct negative consequence to achieve the greatest impact on future behavior. ${ }^{127}$ Accordingly, an official announcement of misconduct and/or an official apology by the responsible party could be a good supportive measure. Oversight from the media, citizen review boards, and elected officials $^{128}$ might also have similar effects. However, such sanctions alone, which primary affect the person's reputation, may be limited in their deterrent effect if not combined with concrete consequences to mitigate the impact of the actual misconduct. $^{129}$

\subsubsection{Criminal Prosecution}

Another alternative to the exclusion of evidence could be criminal prosecution of the officials responsible for the violation of the defendant's rights. Of course, this sanction is quite severe and would need to be proportionate to the misconduct. ${ }^{130}$

Criminal prosecution of police officers is rare in most countries ${ }^{131}$ and, given the controversy around whether it serves its purposes of providing justice and deterring unlawful conduct, it is disputable if such an alternative remedy to exclusionary rules is effective at all. Criminal prosecution of law enforcement comes with many of the same problems as tort actions: a defendant whose rights have been violated often lacks the resources to file such a claim and officials, ${ }^{132}$ even though they may not always be entirely truthful, are generally given more credence than criminal defendants. ${ }^{133}$ Furthermore, the burden of proof is particularly high in criminal prosecutions and would be very difficult to meet. ${ }^{134}$ In reaction to such hurdles it has been proposed that the violation of important procedural rules should, by themselves, constitute contempt of court. ${ }^{135}$ This would mean that the court could

\footnotetext{
${ }^{126}$ Starr, 2009 at 1535 et seq. with further references.

${ }^{127}$ Caldwell/Chase, 1994 at 54 et seq.

${ }^{128}$ Hilton, 2008 at 69.

${ }^{129}$ Shereshevsky, 2015 at 86 and Starr, 2009 at 1527 et seq. and 1536 et seq. both with further references.

${ }^{130}$ Caldwell/Chase, 1994 at 75 et seq.

${ }^{131}$ For the US, Hilton, 2008 at 63 et seq.

${ }^{132}$ Hilton, 2008 at 72 et seq. and Kamisar, 2003 at 130 et seq. with further references.

${ }^{133}$ See above 3.3.1.

${ }^{134}$ Geller, 1975 at 715

${ }^{135}$ See Rychlak, 2010 at 241 et seq. and 249 et seq. regarding illegal searches and seizures.
} 
take the initiative without the prosecution and the matter would be dealt with in summary proceedings. ${ }^{136}$ Another idea is the establishment of a separate office for such claims to guarantee an independent assessment of the case. ${ }^{137}$ An ombudsman system $^{138}$ could also be established. The ombudsman, as an independent official, could be entitled to take penal action against the wrongdoer or attempt to shape police behavior through public relations. ${ }^{139}$

\subsubsection{Other Sanctions}

In cases of impropriety detected in the context of administrative supervision, executive or supervisory bodies should be able to directly impose disciplinary measures. ${ }^{140}$ They could offer counseling to officers and, at least in cases of repeated or intentional violations, impose disciplinary sanctions such as mandatory training, reassignment to less desirable duties, ${ }^{141}$ a prohibition on carrying a weapon, ${ }^{142}$ forfeiture of promotion, removal from duty, ${ }^{143}$ or suspension without pay ${ }^{144}$ - depending on the nature of the misconduct. ${ }^{145}$ The disciplinary sanctions that apply should be communicated clearly and in writing to both the officer and the public in order to reinforce the importance of defendants' rights and to increase trust in law enforcement. ${ }^{146}$

\subsubsection{Interim Conclusion}

Any instrument imposing direct sanctions on law enforcement will face significant barriers to enforcement. Perjury is likely to be encountered regularly ${ }^{147}$ and such means are very difficult to implement from a legislative and enforcement standpoint because of public pressure to convict criminals. There is also strong political

\footnotetext{
${ }^{136}$ Geller, 1975 at 717 with further references; also Rychlak, 2010 at 241 et seq. and 249 et seq. regarding illegal searches and seizures.

${ }^{137}$ This exists, for example, in parts of Switzerland, see Macula, 2019 at 2.1.3.3.

${ }^{138}$ Estreicher/Weick, 2010 at 962 . This exists, for example, in parts of Switzerland, see Macula, 2019 at 2.1.3.3.

${ }^{139}$ Geller 1975 at 717 et seq. with further references.

${ }^{140}$ Wilkey, 1982 at 537 et seq.; Slobogin, 1999 at 422 et seq. considers a pure administrative sanction model with administrative law judges and agency-based litigators as superior to any other remedy.

${ }^{141}$ Caldwell/Chase, 1994 at 69 et seq. and 76.

${ }^{142}$ Hilton, 2008 at 79.

${ }^{143}$ Estreicher/Weick, 2010 at 961; Geller, 1975 at 718 et seq.

${ }^{144}$ Caldwell/Chase, 1994 at 69 and 76; Estreicher/Weick, 2010 at 961; Kamisar, 2003 at 129.

${ }^{145}$ Caldwell/Chase, 1994 at 69.

${ }^{146}$ Hilton, 2008 at 76 et seq.

${ }^{147}$ Kamisar, 2003 at 131.
} 
opposition to restricting police behavior. ${ }^{148}$ Furthermore, separate accountability measures cannot completely replace exclusionary rules or similar measures in cases of severe procedural violations or in cases where the reliability of the evidence may be negatively affected by the way in which it was obtained: The UN Convention Against Torture, for instance, explicitly indicates that statements "made as a result of torture shall not be invoked as evidence in any proceedings"149 and prescribes an "enforceable right to fair and adequate compensation, including the means for as full rehabilitation as possible." ${ }^{\prime 50}$ In a case from 2014, also the ECHR ${ }^{151}$ held that in cases of police incitement in breach of art. $6 \S 1$ ECHR "all evidence obtained [...] must be excluded or a procedure with similar consequences must apply."152

\subsection{Sentence Reductions}

When tainted evidence is used to convict a defendant, the issue of sentence reduction as a remedy arises. According to this approach, tainted evidence is still admitted but the resulting sentence is reduced (potentially considerably). ${ }^{153}$ Some scholars have argued for a combined system of sentence reduction to create an incentive to raising claims in the first place and direct sanctions against the police as a means of deterrence. ${ }^{154}$ Naturally, a defendant might find such an option to be satisfactory compensation for violations of procedural rights - especially if the alternative is not to have any efficient remedy at all.

\footnotetext{
${ }^{148}$ Kamisar, 2003 at 127 et seq. and 137 et seq. with further references.

${ }^{149}$ Except against a person accused of torture as evidence that the statement was made, art. 15 CAT.

${ }^{150}$ Art. 14 (1) CAT.

${ }^{151}$ The ECtHR sets absolute limits to evidence taking in cases of torture, but it is less severe in cases of inhuman treatment, indirect evidence or violations of other fair trial rights, for example, ECtHR (GC), Gäfgen v. Germany, case no. 22978/05, Judgment of 1 June 2010 at $\S 131$ et seq., $\S$ 169 et seq. and 167; ECtHR (GC), Jalloh v. Germany, case no. 54810/00, Judgment of 11 July 2006 at $\S 83$ and 103 et seq.; Gless in Niggli et al. 2014 at art. 141 no. 14 and 22; Thommen/ Samadi, 2016 at 76 et seq.

${ }^{152}$ ECtHR, Furcht v. Germany, case no. 54648/09, Judgment of 23 October 2014 at $\S 64$ and 68.

${ }^{153}$ For instance, it is explicitly mentioned in section 359a of the Dutch Code of Criminal Procedure. According to this provision, the court may "determine that the length of the sentence shall be reduced in proportion to the gravity of the non-compliance with procedural requirements, if the harm or prejudice caused can be compensated in this manner". However, it is the court's prerogative to choose this solution. Alternatively, the court may exclude the tainted evidence or even dismiss the case by baring the prosecution. Sentence reduction is also practised in Canada, see Bick, 2006 at 199 et seq. For information on further models: Starr, 2009 at 1511.

${ }^{154}$ Calabresi, 2003 at 116 et seq.; Caldwell/Chase, 1994 at 68 et seq.; critical: Kamisar, 2003 at 136 et seq. and Starr, 2009 at 1512 et seq. and 1521.
} 


\subsubsection{Advantages}

As we have seen above, courts tend to reject remedies akin to evidence exclusion. ${ }^{155}$ Sentence reduction, by contrast, represents what has been termed an "intermediate remedy" ${ }^{\prime 156}$ because it can be tailored in response to the particular procedural violation and the resulting harm. Given this flexibility, it could also offer an attractive alternative to the "all-or-nothing" nature of exclusionary rules. ${ }^{157}$ Courts would not be required to let a guilty defendant walk free but could also compensate the defendant in the form of sentence reduction, with the discretionary means to limit its scope in order to avoid controversy. ${ }^{158}$ These types of sentence reductions might be more likely to be granted by courts and eventually more effective in safeguarding a defendant's rights than exclusionary rules that remain unapplied. ${ }^{159}$ Although sentence reduction is not as strong a remedy as evidence exclusion (and thus may be more appealing to the public), it can be argued that sentence reduction is a corrective and expressive remedy that publicly embarrasses the wrongdoer (thus deterring further misconduct), while simultaneously recognizing the defendant's rights and dignity. ${ }^{160}$ In addition, it offers the defendant a proportional measure of compensation in the form of years or months of freedom. ${ }^{161}$ Furthermore, it is a simple and practical remedy that can easily be implemented in current legal systems ${ }^{162}$ and could provide a strong incentive to defendants to report misconduct due to the potential for a reduced sentence. ${ }^{163}$

\subsubsection{Shortcomings}

The concept of sentence reduction would likely face many objections. First, sentence reduction is not an option in cases where the misconduct rendered a fair trial impossible. ${ }^{164}$ The option to reduce a sentence in such cases would conflict with international case law and treaties prescribing the exclusion of evidence in severe cases. ${ }^{165}$ Furthermore, although the ECHR has accepted sentence reduction as a

\footnotetext{
${ }^{155}$ See above 1.2.2.

${ }^{156}$ Starr, 2009 at 1511; for a detailed presentation of the pros and cons of sentence reduction see Starr, 2009 at 1520 et seq., 1539 et seq. and 1562 et seq.

${ }^{157} \mathrm{Kafka}, 2001$ at 1928 with further references. See above 1.2.2.

${ }^{158}$ Starr, 2009 at 1520 et seq. and 1539 et seq.

${ }^{159}$ Starr, 2009 at 1513, 1519, 1522, 1539 and 1565 et seq. Bick, 2006 at 221, however, doubts the deterrent effect of sentence reduction.

${ }^{160}$ Starr, 2009 at 1513,1537 and 1539 et seq.

${ }^{161}$ Starr, 2009 at 1513,1541 and 1566.

${ }^{162}$ Starr, 2009 at 1566.

${ }^{163}$ Calabresi, 2003 at 115.

${ }^{164}$ Also Starr, 2009 at 1523, 1564 and 1566.

${ }^{165}$ See also above 3.3.5.
} 
remedy in cases of excessive pre-trial detention, violations of the right to a speedy trial, and unlawful detention conditions, ${ }^{166}$ it also held that in cases of police incitement in breach of art. $6 \S 1$ ECHR, a sentence reduction (even if considerable) does not amount to a "procedure with similar consequences" to an exclusionary rule. It is thus not a sufficient remedy and is not appropriate where evidence has erroneously been admitted. ${ }^{167}$ Similarly, a lack of judicial expediency is not comparable to a violation of the right against self-incrimination, and certainly not to the use of torture as a means of obtaining evidence. That said, the ECHR has remained silent as to what might be equivalent, admissible alternatives to exclusionary rules.

Sentence reduction is also not an appropriate solution in cases where the violation of procedural rules could have also affected the reliability of the evidence. ${ }^{168}$ Since misconduct is often committed deliberately with the aim of increasing the chance of a conviction, sentence reduction may not deter authorities from misconduct where such misconduct improves the likelihood of a conviction. ${ }^{169}$ For example, the reliability of evidence obtained in breach of the right against self-incrimination (particularly in cases of torture) is dubious at best. ${ }^{170}$ Sentence reduction may also encounter the rather serious problem of commodification; law enforcement may get the impression that they can violate suspects' rights in pursuit of a conviction so as long as they are aware of the "price" of the sentence reduction. Such beliefs, if accepted by others, would reduce the stigma associated with procedural misconduct and also reduce any deterrent effect. ${ }^{171}$ Some scholars have gone one step further, arguing that police are primarily interested in convictions and accord less thought to sentencing ${ }^{172}$ in a balancing act of whether or not the misconduct "paid off." 173 Consequently, sentence reduction might not effectively deter police misconduct. It may, however, be effective against prosecutorial misconduct given the numerous incentives they have to pursue longer sentences. ${ }^{174}$

\footnotetext{
${ }^{166}$ Chraidi v. Germany, case no. 65655/01, Judgement of 26 October 2006 at $\S \S 24-25$; Scordino v. Italy, case no. 36813/97, Judgement of 29 March 2006 at $\S \S 185-186 ;$ Mathew v. Netherlands, case no. 24919/03, Judgement of 29 September 2005 at $\S \S 148-149$.

${ }^{167}$ ECtHR, Furcht v. Germany, case no. 54648/09, Judgment of 23 October 2014 at $\S 69$.

${ }^{168}$ Starr, 2009 at $1519,1523,1564,1566$. Accordingly, Starr proposes sentence reduction only as a remedy for speedy trial violations, race discrimination in jury selection and misconduct that is presently deemed "harmless" in the US and currently does not trigger any remedy, see Starr, 2009 at 1548 et seq.

${ }^{169}$ Starr, 2009 at 1523.

${ }^{170}$ Schlauri, 2003 at 100 et seq. with further references. Ruckstuhl, 2006 at 20, however, claims that all influence exerted during the taking of evidence might change the content of the evidence.

${ }^{171}$ Starr, 2009 at 1539 with further references.

${ }^{172}$ Estreicher/Weick, 2010 at 966.

${ }^{173}$ Kamisar, 2003 at 136 with further references.

${ }^{174}$ E.g. political pressure, efficiency efforts, office policy and culture, career interests, the incentive to win and ideologies of justice or crime deterrence, see Starr, 2009 at 1513 and in detail at 1522 et seq and 1531 et seq.
} 
Other arguments against sentence reduction are around the issue of enforcement. These include the difficulty in quantifying the harm caused by the procedural violation in terms of a specific reduction in the sentence, ${ }^{175}$ particularly where formal sentencing guidelines are absent. ${ }^{176}$ This flexibility could potentially add a new source of arbitrariness in sentencing ${ }^{177}$ and tempt judges to raise the minimum sentence of crimes to circumvent the remedy entirely. ${ }^{178}$ The ECHR has also held that where an exact reduction in a sentence is not quantified in a judgment it cannot be deemed measurable. ${ }^{179}$

\subsection{Amnesty and Pardons}

Where authorities have failed to grant a remedy in cases of illegally obtained evidence, and the mistake is eventually realized, they might resort to the delayed remedies of amnesty or pardons. This was the case in Virginia where four sailors who were bullied into confessing to rape and murder were pardoned nearly 20 years after their conviction. ${ }^{180}$ In such cases, amnesty is a delayed, albeit corrective measure, to compensate for the earlier denial of more appropriate remedies, such as evidence exclusion. Certainly, it is better that a remedy be granted late than not at all, though it poses problems similar to those of sentence reductions. If the conviction is based on evidence rendered unreliable due to misconduct, it offers no alternative to remedies granted prior to conviction and, therefore, does not prevent miscarriages of justice. Furthermore, it is not compatible with international case law where torture or severe breaches of a right to a fair trial have occurred. In cases where a defendant was guilty, it also leads to problems of commodification and enforcement, and interferes with sentencing goals. ${ }^{181}$

\subsection{Case Dismissals}

If a violation of procedure is severe, for instance in a case where torture has been used to gather information, the question arises as to whether such an abuse vitiates a

\footnotetext{
${ }^{175}$ I.e. the problem of incommensurability, see Starr, 2009 at 1539 et seq. with counter arguments, inter alia that "liberty is the currency of the criminal law".

${ }^{176}$ Estreicher/Weick, 2010 at 965.

${ }^{177}$ Starr, 2009 at 1542 with counter arguments, inter alia the proposal of fixing sentence reduction in statutory law.

${ }^{178}$ Caldwell/Chase, 1994 at 72; Starr, 2009 at 1562 with further references.

${ }^{179}$ ECtHR, Furcht v. Germany, case no. 54648/09, Judgment of 23 October 2014 at $\S 70$.

${ }^{180}<$ https://www.nytimes.com/2017/03/21/us/norfolk-four-sailors-rape-murder-mcauliffe.html>, accessed 21 November 2018.

${ }^{181}$ See above 3.4.2.
} 
criminal proceeding in such a way that it must be dismissed. ${ }^{182}$ German courts have rejected this proposition, arguing that a dismissal of the case infringes upon the protection of third parties. Moreover, dismissal and the failure to allocate satisfactory sentences jeopardize the important constitutional interest in prosecuting, convicting, and punishing criminal offenders. ${ }^{183}$

\subsection{Interim Conclusion}

There are no alternatives to exclusionary rules that are free from shortcomings. However, until the alternatives are tested in practice and data on their impact is available, it is impossible to definitively predict their outcome. ${ }^{184}$ It may be worthwhile to experiment with some alternatives to determine whether they are better at ensuring compliance with procedural laws and protecting overriding interests, especially individual rights. The most effective way to find this out would be to suspend the operation of exclusionary rules and to replace them with various alternatives in randomly selected jurisdictions. However, it seems more appropriate to experiment with different alternatives as mere supplements to the exclusionary rule and to see how they work in practice. ${ }^{185}$ Another suggestion might be to allow law enforcement agencies to operate free of the exclusionary rule in certain areas (e.g., illegal searches and seizures) under the condition that they implement a set of alternatives to deter police misconduct that are regularly reviewed by the courts. ${ }^{186}$ Notably, some measures discussed in section $\mathrm{C}$ do not require the admission of evidence. Such measures can and should be combined with exclusionary rules (or an alternative) in order to achieve the best possible degree of prevention and compensation.

Real alternatives offering consequences other than the exclusion of evidence, such as sentence reductions, might be particularly helpful as supplementary measures. This could be the case where evidence exclusion does not apply, for example, because the police misconduct is minimal, the defendant is innocent, or the obtained evidence was not crucial for the conviction. It is important that such misconduct

\footnotetext{
${ }^{182}$ For an overview and discussion, see Julius/Schmidt in Gercke et al., 2019 at $§ 206 a$ notes 8 et seq.

${ }^{183}$ The Federal Constitutional Court has held this interest to be part of the principle of Rechtsstaatlichkeit (a state based on the rule of law); see e.g. BVerfG, Decision of 15 January 2009 - 2 BvR 2044/07 (= BVerfGE 122, 248, 273); BVerfG, Judgement of 19 March 2013 - 2 BvR 2628/10, 2 BvR 2883/10, 2 BvR 2155/11 (=BVerfGE 133, 168, 200-201); BVerfG, Decision of 18 December 2014 - 2 BvR 209/14, 2 BvR 240/14, 2 BvR 262/14 (=StV 2015, 413, 415) as well as BGH, Judgement of 18 November 1999 - 1 StR 221/99 (=BGHSt 45, 321, 333-334); BGH, Judgement of 11 December 2013 - 5 StR 240/13 (=NStZ 2014, 277, 280).

${ }^{184}$ Geller, 1975 at 665 .

${ }^{185}$ Geller, 1975 at 689 et seq. and 722; Kamisar, 2003 at 139 et seq.

${ }^{186}$ Estreicher/Weick, 2010 at 951 et seq. and 960 et seq.; similar proposal in: Wilkey, 1982 at 538 et seq.
} 
does not go without consequence. Such a complementary system appears to be the best possible deterrent for misconduct without generally leading to the acquittal of guilty defendants.

\section{Conclusion}

Exclusionary rules have been invoked to solve the dilemma of how the law can address infringements upon procedural rights in criminal investigations, even if at the expense of comprehensive investigation. The various contributions to this volume have shown that exclusionary rules can be designed in a way that helps safeguard individual rights in all systems. However, the goal of protecting individual rights with such rules appears to be achieved best in adversarial systems compared to inquisitorial models outside the Western world.

Ultimately, one of the findings of this research project is that there is no "one size fits all" toolkit for all jurisdictions as the measures must be tailored to fit into each respective system. The exclusion of certain information, for instance, has to be administered differently in adversarial proceedings than it would be in an inquisitorial system. Furthermore, in all systems problems arise that are inherent to evidence exclusion, namely that a court must decide and explain why it will exclude a certain piece of evidence and, thereby restrict the relevant information under its consideration. Due to these problems, some scholars have abandoned the idea of exclusionary rules as an efficient remedy and are in search of alternatives. ${ }^{187} \mathrm{~A}$ thorough analysis of these alternatives reveals some potentially severe downsides. A single "ideal" alternative has not be found, likely in part due to the fact that exclusionary rules have many purposes, some of which are conflicting. ${ }^{188}$ However, the inefficiency and other imperfections of exclusionary rules should not take away from their advantages. A rule with imperfections and gaps, but also clear advantages, should be supplemented rather than abandoned. ${ }^{189}$ In this context, the solution might be a comprehensive system of (1) several possibilities (including well-drafted exclusionary rules) and (2) a set of complementary measures to enhance the achievement of the various purposes of exclusionary rules. Courts could be empowered to choose the consequence for violations of procedural rules that fits best, as it is already the case in the Netherlands. ${ }^{190}$

Finally, it should be realized that the function of exclusionary rules might simply be to serve as illusionary giants or “paper tigers” (徒负虚名 [tu fu xu ming]), something that motivates law enforcement to play by the rules because of the

\footnotetext{
${ }^{187}$ For instance, the detailed and manifold considerations in Geller, 1975 at 689 et seq.; Greco, 2018 at 507.

${ }^{188}$ See above 1.1 .

${ }^{189}$ Geller, 1975 at 669.

${ }^{190}$ Section 359a of the Dutch Code of Criminal Procedure; see above 3.4. in footnote 156.
} 
potential threat of serious consequences. Such rules, even if they remain somewhat obscure, retain the vital practical function of deterring legal authorities from abusing their power.

\section{References}

\section{Books}

Kühne, Hans-Heiner, Strafprozessrecht $9^{\text {th }}$ ed., Heidelberg 2015. [Kühne, 2015]

Oberholzer, Niklaus, Grundzüge des Strafprozessrechts $3^{\text {rd }}$ ed., Bern 2012. [Oberholzer, 2012]

Roxin/Schünemann, Strafverfahrensrecht $29^{\text {th }}$ ed., München 2017. [Roxin/Schünemann, 2017]

Schlauri, Regula, Das Verbot des Selbstbelastungszwangs im Strafverfahren: Konkretisierung eines Grundrechts durch Rechtsvergleichung, Zürich 2003. [Schlauri, 2003]

Summers/Jackson, The Internationalisation of Criminal Evidence: Beyond the Common Law and Civil Law Traditions, Cambridge 2012. [Summers/Jackson, 2012]

\section{Journal Articles}

Amar, Akhil Reed, 'Fourth Amendment First Principles', (1994) 107 Harvard Law Review, 757819. [Amar, 1994]

Bick, Oren, 'Remedial Sentence Reduction: A Restrictive Rule for an Effective Charter Remedy', (2006) 51 Criminal Law Quarterly, 199-237. [Bick, 2006]

Calabresi, Guido, The Exclusionary Rule, (2003) 26 Harvard Journal of Law \& Public Policy, 111-118. [Calabresi, 2003]

Caldwell, Harry M./Chase, Carol A., 'The Unruly Exclusionary Rule: Heeding Justice Blackmun's Call to Examine the Rule in Light of Changing Judicial Understanding about Its Effects outside the Courtroom', (1994) 78 Marquette Law Review, 45-78. [Caldwell/Chase, 1994]

Erb, Volker, 'Beweisverwertungsverbote zum Nachteil des Beschuldigten? Bemerkungen zu einem rechtsstaatlich gefährlichen Irrweg', (2017) 164 Goltdammer's Archiv für Strafrecht, 114-129. [Erb, 2017]

Estreicher, Samuel/Weick, Daniel, 'Opting for a Legislative Alternative to the Fourth Amendment Exclusionary Rule’, (2010) 78 University of Missouri-Kansas City Law Review, 949-966. [Estreicher/Weick, 2010]

Geller, William, 'Enforcing the Fourth Amendment: The Exclusionary Rule and Its Alternatives', (1975) 3 Washington University Law Review, 623-722. [Geller, 1975]

Giannoulopoulos, Dimitrios, 'The Exclusion of Improperly Obtained Evidence in Greece: Putting Constitutional Rights First', (2007) 11 International Journal of Evidence \& Proof, 181-212. [Giannoulopoulos, 2007]

Greco, Luís, 'Warum gerade Beweisverbot? Ketzerische Bemerkungen zur Figur des Beweisverwertungsverbots', in: Ulrich Stein et al. (eds.), Systematik in Strafrechtswissenschaft und Gesetzgebung. Festschrift für Klaus Rogall zum 70. Geburtstag, 585-515. [Greco, 2018]

Hilton, Alicia M., 'Alternatives to the Exclusionary Rule after Hudson v. Michigan: Preventing and Remedying Police Misconduct', (2008) 53 Villanova Law Review, 47-82. [Hilton, 2008]

Ho, Hock Lai, 'The Criminal Trial, the Rule of Law and the Exclusion of Unlawfully Obtained Evidence', (2014) 10 Criminal Law and Philosophy, 109-131. [Ho, 2014] 
Jacobi, Tonja, 'The Law and Economics of the Exclusionary Rule', (2011) 87 Notre Dame Law Review, 101-186. [Jacobi, 2011]

Kafka, Michael T., 'The Exclusionary Rule: An Alternative Perspective', (2001) 27 William Mitchell Law Review, 1895-1939 [Kafka, 2001]

Kamisar, Yale, 'In Defense of the Search and Seizure Exclusionary Rule (Law and Truth - The Twenty-First Annual National Student Federalist Society Symposium on Law and Public Policy - 2002)', (2003) 26 Harvard Jounal of Law \& Public Policy, 119-140. [Kamisar, 2003]

Oaks, Dallin H., 'Studying the Exclusionary Rule in Search and Seizure', (1970) 37 University of Chicago Law Review, 665-757. [Oaks, 1970]

Orfield, Jr., Myron W./Orfield, Jyron W., 'The Exclusionary Rule and Deterrence: An Empirical Study of Chicago Police Narcotics Officers', (1987) 54 University of Chicago Law Review, 1016-1069. [Orfield, 1987]

Orfield, Myron W., 'Deterrence, Perjury, and the Heater Factor: An Exclusioanry Rule in the Chicago Criminal Courts', (1992) 63 University of Colorado Law Review, 75-162. [Orfield, 1992]

Ormerod, David/Birch, Diane, 'The Evolution of the Discretionary Exclusion of Evidence', (2004) Supp Criminal Law Review (50th Anniversary Edition), 138-159. [Ormerod/Birch, 2004]

Pakter, Walter, 'Exclusionary Rules in France, Germany, and Italy', (1985) 9 Hastings International and Comparative Law Review, 1-58. [Pakter, 1985]

Pattenden, Rosemary, 'Admissibility in Criminal Proceedings of Third Party and Real Evidence Obtained by Methods Prohibited by UNCAT', (2006) 10 International Journal of Evidence \& Proof, 1-41. [Pattenden, 2006]

Roberts, Paul/Hunter, Jill, 'Criminal Evidence and Human Rights: Reimaging Common Law Procedural Traditions', (2013) 2 Criminal Law Review, 176-179. [Roberts/Hunter, 2013]

Ruckstuhl, Niklaus, 'Rechtswidrige Beweise erlaubt', (2006) 23 plädoyer, 15-22. [Ruckstuhl, 2006]

Rychlak, Ronald J., 'Replacing the Exclusionary Rule: Fourth Amendment Violations as Direct Criminal Contempt', (2010) 85 Chicago-Kent Law Review, 241-254. [Rychlak, 2010]

Shereshevsky, Yahli, 'Monetary Compensation as a Remedy for Fair Trial Violations Under International Criminal Law', (2015) 18 New Criminal Law Review, 71-99. [Shereshevsky, 2015]

Sklansky, David Alan, 'Is the Exclusionary Rule Obsolete?', (2008) 5 Ohio State Journal of Criminal Law, 567-584. [Sklansky, 2008]

Slobogin, Christopher, 'The Exclusionary Rule: Is It on Its Way Out? Should It Be?', (2013) 10 Ohio State Journal of Criminal Law, 341-355. [Slobogin, 2013]

Slobogin, Christopher, 'Why Liberals Should Chuck the Exclusionary Rule', (1999) 1999 University of Illinois Law Review, 363-446. [Slobogin, 1999]

Solomon Jr, Peter H., 'Authoritarian Legality and Informal Practices: Judges, Lawyers and the State in Russia and China', (2010) 43 Communist and Post-Communist Studies, 351-362. [Solomon, 2010]

Starr, Sonja B., 'Sentence Reduction as a Remedy for Prosecutorial Misconduct', (2009) 97 The Georgetown Law Journal, 1509-1566. [Starr, 2009]

Summers, Sarah/Studer, David, 'Fairness im Strafverfahren? Eine empirische Untersuchung', (2016) 134 Schweizerische Zeitschrift für Strafrecht, 45-72. [Summers/Studer, 2016]

Taslitz, Andrew E., 'Hypocrisy, Corruption, and Illegitimacy: Why Judicial Integrity Justifies the Exclusionary Rule', (2013) 10 Ohio State Journal of Criminal Law, 419-474 [Taslitz, 2013]

Thelle, Hatla, 'Torture in China', (2006) 16 Torture, 268-275. [Thelle, 2006]

Thommen, Marc/Samadi, Mojan, 'The Bigger the Crime, the Smaller the Chance of a Fair Trial? Evidence Exclusion in Serious Crime Cases Under Swiss, Dutch and European Human Rights Law', (2016) 24 European Journal of Crime, Criminal Law and Criminal Justice, 65-86. [Thommen/Samadi, 2016]

Turner, Jenia Iontcheva, 'The Exclusionary Rule as a Symbol of the Rule of Law', (2014) 67 SMU Law Review, 101-126. [Turner, 2014] 
Vetterli, Luzia, 'Kehrtwende in der bundesgerichtlichen Praxis zu den Verwertungsverboten', (2012) 130 Schweizerische Zeitschrift für Strafrecht, 447-70. [Vetterli, 2012]

Webster, Aloysius T., 'Protecting Society's Rights while Preserving Forth Amendment Protections: an Alternative to the Exclusionary Rule', (1982) 23 South Texas Law Journal, 693-718. [Webster, 1982]

Wilkey, Malcolm R., 'Constitutional Alternatives to the Exclusionary Rule', (1982) 23 South Texas Law Journal, 531-557. [Wilkey, 1982]

Wohlers, Wolfgang/Bläsi, Linda, 'Dogmatik und praktische Relevanz der Beweisverwertungsverbote im Strafprozessrecht der Schweiz’ (2015) 134 recht, 158-75. [Wohlers/Bläsi, 2015]

\section{Contributions to Edited Volumes and Annotated Law}

Eser, Albin, 'Adversatorische und inquisitorische Verfahrensmodelle. Ein kritischer Vergleich mit Strukturalternativen', in: Schroeder, Friedrich-Christian, Kudtratov, Manuchehr (eds.): Die strafprozessuale Hauptverhandlung zwischen inquisitorischem und adversatorischem Modell: eine rechtsvergleichende Analyse am Beispiel des deutschen und des zentralasiatischen Strafprozessrechts, Frankfurt am Main, 2014, 11-29. [Eser, 2014]

Gercke, Björn/Julius, Karl-Peter/Temming, Dieter/Zöller, Mark A. (eds.), Strafprozessordnung. Heidelberger Kommentar $6^{\text {th }}$ ed., Heidelberg 2019. [Julius/Schmidt in Gercke et al., 2012]

Gless, Sabine/Martin, Jeannine, 'Water Always Finds its Way - Discretion and the Concept of Exclusionary Rules in the Swiss Criminal Procedure Code', in: Hodgson, Jackie/Caianiello, Michele (eds.), Discretionary Criminal Justice in a Comparative Context, Durham 2015, 159 184. [Gless/Martin, 2015]

Gless, Sabine, 'Protecting Human Rights through Exclusionary Rules? - Highlights on a Conflict in Criminal Proceedings from a Comparative Perspective', in: Böse/Bohlander/Klip/Lagodny (eds.), Justice without Borders. Essays in the Honour of Wolfgang Schomburg, Leiden 2018, 159-179. [Gless, 2018]

Ho, Hock Lai, 'Criminal Justice and the Exclusion of Incriminating Statements in Singapore', in: Gless, Sabine/Richter, Thomas (eds.), Do Exclusionary Rules Ensure a Fair Trial? A Comparative Perspective on Evidentiary Rules, Cham 2019, 213-252. [Ho, 2019a]

Ho, Hock Lai, 'The Fair Trial Rationale for Excluding Wrongfully Obtained Evidence', in: Gless, Sabine/Richter, Thomas (eds.), Do Exclusionary Rules Ensure a Fair Trial? A Comparative Perspective on Evidentiary Rules, Cham 2019, 283-305. [Ho, 2019b]

Jiang, Na , 'The Potential to Secure a Fair Trial Through Evidence Exclusion: A Chinese Perspective', in: Gless, Sabine/Richter, Thomas (eds.), Do Exclusionary Rules Ensure a Fair Trial? A Comparative Perspective on Evidentiary Rules, Cham 2019, 163-211. [Jiang, 2019]

Knickmeier, Susanne, 'Securing a Fair Trial Through Exclusionary Rules: Do Theory and Practice Form a Well-Balanced Whole?', in: Gless, Sabine/Richter, Thomas (eds.), Do Exclusionary Rules Ensure a Fair Trial? A Comparative Perspective on Evidentiary Rules, Cham 2019, 329-347 [Knickmeier, 2019]

Lin, Yu-Hsiung et al., 'The Potential to Secure a Fair Tiral Through Evidence Exclusion: A Taiwanese Perspective', in: Gless, Sabine/Richter, Thomas (eds.), Do Exclusionary Rules Ensure a Fair Trial? A Comparative Perspective on Evidentiary Rules, Cham 2019, 131-161. [Lin et al., 2019]

Löwe, Ewald/Rosenberg, Werner (eds.), Die Strafprozessordnung und das Gerichtsverfassungsgesetz: StPO Band 4: $\xi \oint 112-15026^{\text {th }}$ ed., Berlin 2007. [Gless in Löwe/Rosenberg, 2007]

Macula, Laura, 'The Potential to Secure a Fair Tiral Through Evidence Exclusion: A Swiss Perspective', in: Gless, Sabine/Richter, Thomas (eds.), Do Exclusionary Rules Ensure a Fair Trial? A Comparative Perspective on Evidentiary Rules, Cham 2019, 15-60. [Macula, 2019] 
Niggli, Marcel Alexander/Heer, Marianne/Wiprächtiger, Hans (eds.), Basler Kommentar. Schweizerische Strafprozessordnung/Jugendstrafprozessordnung (StPO/JStPO) $2^{\text {nd }}$ ed., Basel 2014. [Gless in Niggli et al., 2014]

Thaman, Stephen C., 'Chapter 17. Balancing Truth Against Human Rights: A Theory of Modern Exclusionary Rules', in: Thaman, Stephen C. (ed.), Exclusionary Rules in Comparative Law, Ius Gentium: Comparative Perspectives on Law and Justice, vol. 20, Dordrecht 2013, 403 446. [Thaman, 2013]

Turner, Jenia I./Weigend, Thomas, 'The Purposes and Functions of Exclusionary Rules: A Comparative Overview', in: Gless, Sabine/Richter, Thomas (eds.), Do Exclusionary Rules Ensure a Fair Trial? A Comparative Perspective on Evidentiary Rules, Cham 2019, 255-282 [Turner/Weigend, 2019]

Turner, Jenia I., 'Regulating Interrogations and Excluding Confessions in the United States: Balancing Individual Rights and the Search for the Truth', in: Gless, Sabine/Richter, Thomas (eds.), Do Exclusionary Rules Ensure a Fair Trial? A Comparative Perspective on Evidentiary Rules, Cham 2019, 93-129. [Turner, 2019]

Weigend, Thomas , 'The Potential to Secure a Fair Trial Through Evidence Exclusion: A German Perspective', in: Gless, Sabine/Richter, Thomas (eds.), Do Exclusionary Rules Ensure a Fair Trial? A Comparative Perspective on Evidentiary Rules, Cham 2019, 61-92. [Weigend, 2019]

Wohlers, Wolfgang, 'Verwertungs-, Verwendungs- und/oder Belastungsverbote - die Rechtsfolgenseite der Lehre von den Beweisverwertungsverboten', in: Herzog, Felix/ Schlothauer, Reinhold/Wohlers, Wolfgang (eds.), Rechtsstaatlicher Strafprozess und Bürgerrechte. Gedächtnisschrift für Edda Weßlau, Berlin 2016, 427-444. [Wohlers, 2016]

Zuo, Weimin/Lan, Rongjie, 'Exclusionary Rule of Illegal Evidence in China: Observation from Historical and Empirical Perspectives', in: Gless, Sabine/Richter, Thomas (eds.), Do Exclusionary Rules Ensure a Fair Trial? A Comparative Perspective on Evidentiary Rules, Cham 2019, 307-328. [Zuo/Lan, 2019]

Sabine Gless teaches criminal law, criminal procedure, and international criminal law at the University of Basel, Switzerland. Her research includes comparative work in evidence law and international cooperation with a focus on human rights issues and exclusionary rules.

Laura Macula holds a Master's degree in law (summa cum laude). Her master's thesis discusses possible conflicts between the right against self-incrimination and information duties under the Swiss financial market regulation. It was published in 2016. Her doctoral theses analyzes exclusionary rules from a comparative perspective with a particular focus on the exclusion of exonerating evidence. 
Open Access This chapter is licensed under the terms of the Creative Commons Attribution 4.0 International License (http://creativecommons.org/licenses/by/4.0/), which permits use, sharing, adaptation, distribution and reproduction in any medium or format, as long as you give appropriate credit to the original author(s) and the source, provide a link to the Creative Commons license and indicate if changes were made.

The images or other third party material in this chapter are included in the chapter's Creative Commons license, unless indicated otherwise in a credit line to the material. If material is not included in the chapter's Creative Commons license and your intended use is not permitted by statutory regulation or exceeds the permitted use, you will need to obtain permission directly from the copyright holder.

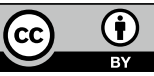

